\title{
BOTANICAL STUDIES ON THE MICROPROPAGATION OF DATE PALM (Phoenix dactylifera, L.) USING TISSUE CULTURE TECHINIQUE: \\ I- EFFECTS OF ANTIOXIDANT; AOS ON BROWNING CONTROL AND RELATED COMPOUNDS. \\ Helaly, M.N.*; M.M. Darwish*; Z. A. Mohamed ; A.A. Hegazy** and Hanan A.M.R.El-Hosieny* \\ * Agric Botany Dept., Faculty of Agric., Mansoura Univ., Egypt \\ ** Genetic of Engineering and Biotech. Research Inst., Menofia Univ
}

\begin{abstract}
Antioxidants; ascorbic and /or citric acids in Bartamoda and sakkoty $\operatorname{cv}(\mathrm{s})$ increased F.Wt of the initial explant, its growth value and total phenols whereas decreased browning degree of the tissues and the adjacent medium as well as the concentrations of $\mathrm{H}_{2} \mathrm{O}_{2}$ and proline. AOs increased the concentrations of AsA and GSH in the developed explant of both date palm (Phoenix dactylifera $L$,) cv(s). AsA showed an additive effects to that of citric on increasing non-enzymatic and enzymatic antioxidants concentrations in both $\mathrm{cv}(\mathrm{s})$.

Bartamuda CV showed, in general, higher F.Wt as well as concentrations of total phenols, $\mathrm{H}_{2} \mathrm{O}_{2}$ and proline, than Sakkoty cv. However,concentrations of AsA and GSH as well as CAT, GPOD and SOD in Baramuda cv was found to be less than that of Sakkoty cv over all treatments. This indicated that Bartamuda cv has high ability to used AsA and GSH specially the latter, in the synthesis of thio containing molecules, particularly salfhydryl-containin amino acids.

Keywords: Phoenix dactylifera - Proline - Reduced glutathione - Guaiacol peroidase -Superoxide dismutase

\section{INTRODUCTION}

Date palm (Phoenix dactylifera, L; Palmaceae, Arecaceae) micropropagation has been initiated to produce plantlets from economically important cultivars such as Bartamuda, Sakkoty and others. It has been considerable interest in developing tissue culture micropropagation techniques to obtain large number of plantlets and reduce the dependence on offshoots propagation. Tisserat (1979 a and b) found that, date palm tissues are especially susceptible to lethal browning substances discharged from the explants which withered and died (Khalil et al., 1983). The cultured explants on nutrients medium, release toxic substances such as phenolic compounds which induce rowning and inhibit tissues growth. Thereafter, the explants deteriorate and go to die. due to a conjugation between phenols and the protein. Subsequently, the enzymes loss their activity (Nash and Davies, 1972). They added that, the increase in phenolic compound production has been associated with a decrease in growth and a decline in protein synthesis. Phenolic compounds oxidized and become quinones (toxic compounds) by the enzymes polyphenol oxidase and peroxidase ( $\mathrm{Hu}$ and Wang, 1983). These quinones make browning of the tissues, begin from yellow to dark brown to black colour and lead it to die.
\end{abstract}


The increase in the production of phenolic compounds has been associated with high levels of exogenous sugars (Rhodes and Wooltoron 1978). Hegazy (2003) found a highly significant interaction between the concentration of auxin and sucrose as well as phenolic compounds in the media. Grambow and Langenbeck-Schwich (1983) reported that, the substitution pattern of phenols (auxin protectors) affects the rate of IAA degradation. Some substituted monophenolic increased its rate whereas others depressed it.

To minimize browning ,Forrest (1969) indicated that, light stimulated flavonoid synthesis in tea (Camellia sinensis, $\mathrm{H}$.). and reduced the production of phenols and browning as well as acid culture establishment. Similar results were reported by El-Shafey et al (1999) on date palm Siwi cv. Tisserat (1984 $a \& b)$ investigated the anti-browning effect of a number of substances such as ascorbic acid, dihydroxynaphthalene, dimethyl sulfoxide and PVP but he found that, all the previous compounds were not effective. Zaid (1986) reported that, the browning of tissues may be prevented by presoaking explants in antioxidant solution of $150 \mathrm{mg} / \mathrm{l}$ citric and $100 \mathrm{mg} / \mathrm{l}$ ascorbic acid, as well as by using small explants and subculturing on fresh medium for short period of incubation. Pierik (1989) reported that, the most important aspects of A. C was adsorption of toxic brown/black pigments (phenol-like compounds, and melanin) and other unknown colorless toxic compounds and this in turn, might promote somatic embryogenesis. Similarly lbrahim and Hegazy (2001 a\&b) mentioned that, addition of A. C. to date palm culture medium at the level of $1.5 \mathrm{~g} / \mathrm{l}$ was superior for minimizing browning.

Some researchers who works on date palm tissue culture, embloyed some nutrients, amino acids and PVP to decrease browning. Apavatjrut and Black (1977) and Hegazy (2003) suggested that, browning could be eliminated by employing a nutritionally balanced medium. Lee and Kirby (1986) reported that, when Pseudotsuge menziesii grown on glutamine at concentrations 10,30 and $50 \mathrm{mM}$, cell cultures grew rapidly with a shortened log phase. Bekkaoui et al. (1987) found that, the addition of $5 \mathrm{mM}$ glutamine to the cell suspension culture medium of Picea glauce were necessary for callus formation. Pierik (1987 and 1989) suggested that, the addition of three amino acids (glutamine, argeninine and asparagines) may minimize browning. Similarly, Suprasanna et al. (1994) found that, L - proline and Lglutamine increased the frequency of embryogenic callus production and ecreased browning. Prathanturarug et al (1996) studied the effects of antioxidants, absorbents, light and dark conditions on browning phenomenon and found that, PVP-10 at $1 \mathrm{~g} / \mathrm{l}$ reduced browning of Nees explants. They added that, citric acid at $50 \mathrm{mg} / \mathrm{l}$ increased shoot elongation and showed an antibrowning properties. Similarly, activated charcoal decreased browning but caused some hyperhydricity symptoms. Incubation under low light intensity at 600 Lux gave the best antibrowning effect. However they repoted that, pretreatment with antibrowning before incubation has no effect on reducing browning.

The present investigation aimed to study the effects of antioxidant; AOs on browning control and related compounds 


\section{MATERIALS AND METHODS}

The present investigation was carried out at the plant tissue culture Dept .,Genetic of Engineering and Biotechnology Research Institute(G E B R I) EL-Sadat city ,Menofia Unvi. Egypt and the Laboratories of Agric.Bot.Dept., Faculty of Agric. Mansoura Univ. Egypt, during the period of $2003-2007$.

Femal date palm (phoenix dactylifera, L),Bartamuda and Sakkoty $\mathrm{cv}(\mathrm{s})$, which commonly known as an important dried cv(s) grown at Aswan governorate ,Egypt were used to exploring the alleviation effects of antioxidant on controlling browning, as well as related compounds .

Explants from each $\mathrm{cv}(\mathrm{s})$ were prepared as previously maintained (ElHosiney Hanan, 2008) and cultured in MS basal nutrient media (Table 1) with or without ascorbic acid $(75 \mathrm{ml} / \mathrm{l})$, citric acid $(75 \mathrm{ml} / \mathrm{l})$ and ascorbic + citric. $(75+75 \mathrm{mg} / \mathrm{l})$. Gelrite as a gelling agent at $1.5 \mathrm{~g} / \mathrm{l}$ was used. The $\mathrm{pH}$ was adjusted at 5.7-5.8 prior to the addition of gelrite.

Each treatment was replicated 6 times ( 6 culturing jars; $250 \mathrm{ml}$.). The nutrient media for each treatment was distributed into culture jars, each one contained $35 \mathrm{ml}$ of the specific prepeared medium.

The culture jars were immediately capped with polypropulin closure and autoclaved at $121^{\circ} \mathrm{C}, 15 / 1 \mathrm{bs} / \mathrm{inch}^{2}$ for 20 minutes

Sterilized shoot tip explants were cultured on the specific medium and incubated at $25-27^{\circ} \mathrm{C}$ for $16 / 18 \mathrm{hrs}$ day/night condition using white fluorescent tubes giving intensity of about 1500 Lux. The incubation was took place for 6 months with 4-sub-culturing, 6 weeks intervals. At each sub-culturing date, all survived plants were transferred and recultured on the same fresh specific media and the number as well as percentages of shoot tip explants which produced axillary buds were recorded.

To prepare stock solution $\mathrm{F}$ : dissolve each constituents in $200 \mathrm{ml}$ distilled water; heat $\mathrm{Na}_{2} \mathrm{EDTA}$ solution; with continuous stirring add $\mathrm{Fe}$ $\mathrm{SO}_{4} 7 \mathrm{H}_{2} \mathrm{O}$ solution when cool dilute to $1000 \mathrm{ml}$ with distilled water

Myo-Inosito; $1 \mathrm{~g} / \mathrm{l}$, Biotin; $0.2 \mathrm{mg} / \mathrm{l}$, Asparagen; $125 \mathrm{mg} / \mathrm{l}$, Glutamine; $200 \mathrm{mg} / \mathrm{l}$ and Adenine Sulfate $; 20 \mathrm{mg} / \mathrm{l}$ were added respectively to the MS medium as suggested by the authoress (El-Hosieny, Hanan, 2002).

At the end of incubation period, 6 months, the following data were recorded : - Browning (Pottino 1981) and Fresh weight; F.Wt of the developed exlpant, Concentrations of $\mathrm{H}_{2} \mathrm{O}_{2}$ (Velikova et al, 2000)., Ascorbic acid (Cakmak and Marschner 1992) and Glutathione (GSH) (Abd El-Salam, Heba 2006) were determined. The activity of the antioxidant enzymes: catalase; CAT (Velikova et al, 2000) , guaiacol peroxidase; GPOD ( Urbanek et al, 1991) and, superoxive To prepare stock solution F: dissolve each constituents in $200 \mathrm{ml}$ distilled water; heat $\mathrm{Na}_{2}$ EDTA solution; with continuous stirring add $\mathrm{Fe} \mathrm{SO} 47 \mathrm{H}_{2} \mathrm{O}$ solution when cool dilute to $1000 \mathrm{ml}$ with distilled water

Myo-Inosito; $1 \mathrm{~g} / \mathrm{l}$, Biotin; $0.2 \mathrm{mg} / \mathrm{l}$, Asparagen; $125 \mathrm{mg} / \mathrm{l}$, Glutamine; $200 \mathrm{mg} / \mathrm{l}$ and Adenine Sulfate $; 20 \mathrm{mg} / \mathrm{l}$ were added respectively to the MS medium as suggested by the authoress (El-Hosieny, Hanan, 2002). 
dismutase ;SOD (Van Rossun et al 1997) as well as concentrations of proline: (Bates et al, 1973), and total soluble phenols (Swain and hills , 1959 and Danial and George, 1972) were also determined.

All data were subjected to statistical analysis according to(Gomez and Gomez 1984).

Table 1 :Composition of basal nutrient medium of Murashige and Skoog; MS (1962).

\begin{tabular}{|c|c|c|c|c|}
\hline Stock solution S.S. & Constituents & g/liter S.S. & $\begin{array}{l}\text { mg/liter } \\
\text { medium }\end{array}$ & $\begin{array}{l}\text { To make up } \\
\text { liter of MS } \\
\text { medium } \mathrm{ml}\end{array}$ \\
\hline$A$ & $\mathrm{NH}_{4} \mathrm{NO}_{3}$ & 82.5 & 1650 & 20 \\
\hline$B$ & $\mathrm{KNO}_{3}$ & 95.0 & 1900 & 20 \\
\hline \multirow{5}{*}{ C } & $\mathrm{H}_{3} \mathrm{BO}_{3}$ & 1.24 & 6.2 & \multirow{5}{*}{5} \\
\hline & $\mathrm{KH}_{2} \mathrm{PO}_{4}$ & 0.05 & 170 & \\
\hline & $\mathrm{KI}$ & 34.0 & 0.83 & \\
\hline & $\mathrm{Na}_{2} \mathrm{MoO}_{4} 2 \mathrm{H}_{2} \mathrm{O}$ & 0.005 & 0.25 & \\
\hline & $\mathrm{CoCl}_{2} 2 \mathrm{H}_{2} \mathrm{O}$ & 0.166 & 0.025 & \\
\hline $\mathrm{D}$ & $\mathrm{CaCl}_{2} 2 \mathrm{H}_{2} \mathrm{O}$ & 88.00 & 440 & 5 \\
\hline \multirow{4}{*}{ E } & $\mathrm{MgSO}_{4} 7 \mathrm{H}_{2} \mathrm{O}$ & 74.00 & 370 & \multirow{4}{*}{5} \\
\hline & $\mathrm{MnSO}_{4} 4 \mathrm{H}_{2} \mathrm{O}$ & 1.72 & 22.3 & \\
\hline & $\mathrm{ZnSO}_{4} 7 \mathrm{H}_{2} \mathrm{O}$ & 4.46 & 8.6 & \\
\hline & $\mathrm{CuSO}_{4} 5 \mathrm{H}_{2} \mathrm{O}$ & 0.005 & 0.025 & \\
\hline \multirow{2}{*}{$F$} & $\mathrm{Na}_{2} \mathrm{EDTA}$ & 7.45 & 37.25 & \multirow[b]{2}{*}{5} \\
\hline & $\mathrm{FeSO}_{4} 7 \mathrm{H}_{2} \mathrm{O}$ & 5.57 & 27.85 & \\
\hline \multirow{4}{*}{$G$} & Thiamine $\mathrm{HCl}$ & 0.2 & & \multirow{4}{*}{5} \\
\hline & Nicotinic acid & 0.1 & & \\
\hline & Pyridoxine $\mathrm{HCl}$ & 0.1 & & \\
\hline & Glycin & 0.4 & & \\
\hline
\end{tabular}

Stock solution F: is made differentially from the others.

\section{RESULTS AND DISCUSSION}

Data in Table 2 show that $\mathrm{F}$. Wt of the initial explant, growth value (data not presented) and total phenols were increased whereas browning degree of the tissues and the adjacent medium as well as the concentrations of $\mathrm{H}_{2} \mathrm{O}_{2}$ and proline were decreased due to AOs application. The decrease was more pronounced in response to ascorbic + citric acids treatment. in both genotype of date palm. The presence of the two antioxidants recorded additive effects in this respect in both genotypes. There is no significant difference between the two AOs used in both $\mathrm{cv}(\mathrm{s})$. Browning may be due to the oxidation of polyphenols and the formation of quinones which are highly reactive and toxic to date palm tissues. El-Meskaoui and Tremblay (2001) suggested that ethylene could cause tissue browning, it activate the synthesis of oxidative enzymes or inhibit the synthesis of protective enzymes. In addition, 'date in the present investigation

show that over all treatments, Bartamuda cv showed, in general,high F.Wt as well as concentrations of total phenols $\mathrm{H}_{2} \mathrm{O}_{2}$ and proline values compared with Sakkoty cv. The lowest F.Wt values was noticed in MS 
treatment with Sakkoty cv compared with the corresponding decrease noticed in Bartamuda cv. In addition, the highest reduction in the concentrations values of $\mathrm{H}_{2} \mathrm{O}_{2}$ and proline were recorded in the presnce of ascorbic and citric acids together. It seems also that, ascorbic acid was more effective in this respect.

Table 2:Effects of MS media with or without antioxidants; AOs on fresh weigh; F.Wt (g/explant) of the explant at the end of callus stages (24 weeks), Browning degree, enzymatic and non enzymatic antioxidants as well as certain other browning- related metabolites.

\begin{tabular}{|c|c|c|c|c|c|c|c|c|c|c|c|}
\hline $\begin{array}{l}\text { Gen- } \\
\text { otype } \\
\text { cv(s) }\end{array}$ & $\begin{array}{l}\text { Treatments } \\
\mathrm{mgl}^{-1}\end{array}$ & $\begin{array}{l}\text { F.Wt } \\
\text { g/jar }\end{array}$ & $\begin{array}{l}\text { Browning } \\
\text { degree }\end{array}$ & TSP & $\mathrm{H}_{2} \mathrm{O}_{2}$ & Proline & SOD & AsA & GSH & CAT & GPOD \\
\hline \multirow{5}{*}{$\begin{array}{l}\text { Barta } \\
\text { muda }\end{array}$} & MS Control & 5.2 & 4 & 0.8 & 1.07 & 1.59 & 150 & 250 & 50.3 & 70 & 8 \\
\hline & MS+Ascorbic & 6.0 & 3 & 1.1 & 0.61 & 0.15 & 106 & 317 & \begin{tabular}{|l|}
74.9 \\
\end{tabular} & 99 & 10 \\
\hline & MS+Citric & 6.2 & 3 & 1.1 & 0.60 & 0.75 & 110 & 333 & 68.0 & 92 & 9 \\
\hline & $\mathrm{MS}+\mathrm{AsA}+\mathrm{Cit}$ & 7.8 & 2 & 1.8 & 0.56 & 0.60 & 206 & 360 & 86.5 & 110 & 13 \\
\hline & Mean & 6.3 & 3 & 1.2 & 0.71 & 0.77 & 143 & 315 & 63.18 & 9275 & 10 \\
\hline \multirow{5}{*}{$\begin{array}{l}\text { Sakko } \\
\text { ty }\end{array}$} & MS control & 5.08 & 4 & 0.6 & 1.03 & 0.78 & 250 & 300 & 66.6 & 107 & 13 \\
\hline & MS+Ascorbic & 5.40 & 3 & 0.8 & 0.60 & 0.44 & 256 & 330 & 80.3 & 110 & 13 \\
\hline & MS+citric & 5.44 & 3 & 0.9 & 0.57 & 0.44 & 264 & 346 & 86.8 & 120 & 14 \\
\hline & $M S+A S A+C i t$ & 6.14 & 2 & 1.1 & 0.50 & 0.38 & 270 & 383 & 103.9 & 137 & 15 \\
\hline & Mean & 5.52 & 3 & 3.1 & 0.68 & 0.51 & 260 & 339.75 & 84.4 & 118.5 & 13.75 \\
\hline \multirow{4}{*}{ Mean } & MS Control & 5.14 & 4 & 0.7 & 1.05 & 1.19 & 200 & 275 & 58.45 & 88.5 & 10.5 \\
\hline & MS+Ascorbic & 5.7 & 3 & 0.95 & 0.61 & 0.30 & 181 & 323.5 & 77.6 & 104.5 & 11.5 \\
\hline & MS+Citric & 5.82 & 3 & 1.00 & 0.59 & 0.60 & 178 & 339.5 & 77.4 & 106.0 & 11.5 \\
\hline & $\mathrm{MS}+\mathrm{AsA}+\mathrm{Cit}$ & 6.97 & 2 & 1.45 & 0.53 & 0.49 & 238 & 371.5 & 95.2 & 123.5 & 14.0 \\
\hline \multicolumn{2}{|c|}{$\begin{array}{l}\text { Genotype; A } \\
\text { Treatments; B }\end{array}$} & $\begin{array}{l}0.07 \\
1.08\end{array}$ & & \multicolumn{2}{|c|}{$\begin{array}{ll}0.02 & 0.03 \\
0.02 & 0.04\end{array}$} & $\begin{array}{l}0.01 \\
0.01\end{array}$ & $\begin{array}{l}2.0 \\
2.6\end{array}$ & $\begin{array}{l}4.2 \\
4.5\end{array}$ & $\begin{array}{l}3.5 \\
3.7\end{array}$ & $\begin{array}{l}1.2 \\
1.3\end{array}$ & $\begin{array}{l}0.07 \\
0.09\end{array}$ \\
\hline \multicolumn{4}{|c|}{$\begin{array}{l}\text { Genotype } x \text { treatments } \\
(\mathrm{AxB})\end{array}$} & 0.03 & .06 & 0.02 & 3.1 & 6.1 & 4.1 & 1.6 & 1.10 \\
\hline
\end{tabular}

(AxB) 1.07

F.Wt = Fresh weight (g / explant)

TSP $=$ Total soluble phenols (mg/g F.Wt)

Browning degree according to Pottino (1981)

Proline ( $\left.\mathrm{mg} \mathrm{g}^{-1} \mathrm{~F} . \mathrm{Wt}\right)$

AsA $=$ Ascorbic acid $\left(\mu g^{-1} F . W t\right)$

GSH = Reduced glutathione $\left(\mu \mathrm{g} \mathrm{g}^{-1} \mathrm{~F} . \mathrm{Wt}\right)$

GPOD $=$ Guaiacol peroidase $\left(\mu \mathrm{g} \mathrm{g}^{-1} \mathrm{~F} . \mathrm{Wt}\right)$

$\mathrm{H}_{2} \mathrm{O}_{2}=$ Hydrogen peroxide $\left(\mu \mathrm{M} \mathrm{g}{ }^{-1} \mathrm{~F} . \mathrm{Wt}\right)$

SOD $=$ Superoxide dismutase $\left(\mu \mathrm{g} \mathrm{g}^{-1} \mathrm{~F} . \mathrm{Wt}\right)$

Cit = Citric acid

CAT $=$ Catalase $\left(\mu \mathrm{g} \mathrm{g}^{-1} \mathrm{~F} . \mathrm{Wt}\right)$

The increasing effects of AOs on F.Wt may be due to their antioxidative effects on increasing mitotic activity (Jiang et al, 2001, and Munne-Bosch, 2005). A specific roles of the AOs used were previously reported by Abdel-Salam, Heba (2006) who reported that AOs many contribute to their alleviation effect and the role of reduced glutathione. $\mathrm{He}$ added that, the alleviation effect of AsA may be due to its enhancing effect on cell division and synthesis of hydroxy-proline-rich protein. Wingate et al, (1988) found that AOs regulated the gene expression and being the precursor of phytochelatins

The increasing effects of AOs on total phenols may be due to their effects on reduction the phenollic compounds oxidation (Murashige, 1974). Ichihashi and Kako(1977) found that AOs did not prevent phenols oxidaton 
but prevent quinones polymerization and reduced the probability to react wih protein. The reduction effects of AOs on brwning as well as the negative relationships between browning degree and total soluble phenols were previously mentioned (Hegazy, 2003)

It was found that phenolic compounds was essential for multiplication and rooting in micropropagation of many plant species (Bekheet et al,2008). Al-Khateeb (2008) reported that browning may be due to the oxidation of the various wounding exudates polyphenols compounds to form quinones, highly reactive compounds which polymerize rapidly with protein by covalent bonds which are toxic for date palm tissue growth and development. In intact tissue, phenolic compounds were apparently situated in separate pools or compartments within the cells. These pools are integrated with wounding and oxidized. The inhibitory action of phenols may results from its oxidation to quinones by poly phenols oxidase and peroxidase and subsequent binding with protein, such process may lead to the loss of various enzyme activities (Hu and Wang, 1983). Hegazy (2003) reported that, phenolic exudate released compounds were decreased from the explants after $24 \mathrm{~h}$ in the media containing high level of ascorbate and citrate.

Increasing $\mathrm{H}_{2} \mathrm{O}_{2}$ as well as other reductive oxygen species; AOs leading to oxidative stress is a principal component of their damaging effect on plant tissues (Schutzendubel and Polle, 2002).

The protective role of $\mathrm{AOs}$ against $\mathrm{H}_{2} \mathrm{O}_{2}$ accumulation was previously reported (Cheng, 2003; Guo et al, 2005 and Munne-Bosch, 2005) . According to Abd El-Slam, Heba 2006), AsA reduced glutathione; GSH and $\propto-$ tocopherol ; $T$ have each been shown to act as antioxidants in the detoxification of reactive oxygen species; ROS in aerobic cells. They have central and interrelated roles acting both chemically and as substrates in enzyme-catalyzed detoxification reactions. Ascorbic acid; AsA is an important compound of the plant antioxidant defence system and serves as a reductant for the peroxidative removal of $\mathrm{H}_{2} \mathrm{O}_{2}$. Reduced glutathione; $\mathrm{GSH}$ directly reduces most of reactive oxygen species; ROS and maintain the accorbate pool in plant cell. Munne-Bosch, (2005) added that under stress conditions, tocopherol; $\mathrm{T}$ prevents the propagation of lipid peroxidation by scavenging reactive oxygen species; ROS .

The reduction effects of $\mathrm{AOs}$ on proline concentration may be due to their stress alleviation effects (Abd El-Slam Heba, 2006) in addition to their enhancing effects on cell division (Sanchez-Fernandez, et al, 1997). These effects leed to an acceleration of proline consumption in the synthesis of hydro-xyproline-rich proteins which are necessary for progression through the cell cycle (Arrigoni et al ,1992).

Data tablueted in the same table show also that AOs increased the concentrations of AsA and GSH in the developed explant of both date palm (phoenix dactylifera $L$,) $\mathrm{cv}(\mathrm{s})$. The enhancing effects of ascorbic acid treatment was less than those of citric acid treatment on AsA and GSH concentrations. AsA showed an additive effects to that of citric on increasing non-enzymatic antioxidants concentrations in both $\mathrm{cv}(\mathrm{s})$; since treatment MS+ cltric showed highest values in this respect. 
Helaly, M.N. et al.

Antioxidants (AsA and/or citric,) increased the activity of the antioxidant enzymes in the developed explants in both genotypes date palm. Ascorbic + Citric acids treatment led to the highest induction in the activity of all enzymes estimated.

The interaction effects between the genotype and the AOs treatments on antioxidants enzymes activaties were significant. These results indicated that AOs induced oxidative stress. Smeets et al, (2005) reported that, plant cells respond to elevated levels of oxidative stress by activating their antioxidative defence system and the first group of enzymes involved in this defence are the ROS- quenching enzymes such as, CAT, PODS and SOD. Cheng (2003) recorded that, CAT, PODS and SOD are important enzymes for plant adaptation to environmental stresses as the harmonious interaction of the three enzymes make the balance between ROS production and elimination, thus keeping the level of ROS in plant tissues low, to prevent the injury of cells. In peroxisomes, $\mathrm{H}_{2} \mathrm{O}_{2}$ can be destroyed by CAT. CAT produces molecular oxygen and water from two molecules of $\mathrm{H}_{2} \mathrm{O}_{2}$. Since these two molecules must impinge simultaneously at the active site, CAT has a very high maximum velocity. PODS is an important role in scavenging $\mathrm{H}_{2} \mathrm{O}_{2}$ and organic peroxidase (Smeets, et al, 2005). Moreover, Abd El-Salam, Heba, (2006) reported that SOD causes the catalytic dismutation of potentially toxic superoxide anion radical $\left(\mathrm{O}^{2-}\right)$ to $\mathrm{H}_{2} \mathrm{O}_{2}$ whereas, CAT decomposes $\mathrm{H}_{2} \mathrm{O}_{2}$ to water and oxygen molecule, both enzymes provide an efficient mechanism for the removal of free radicals from the cells .

It has been concluded that, controlling browning phenomenon is a general goal by tissue culture workers. Inducing antioxidative enzyme activities is important to overcome oxidative stress due to the imposition of environmental stress (Foyer et al, 1994). This induction may be due to an enhanced gen (s) activity, since overexpression of genes encoding these enzymes in several transgenic plant species confers protection aganest free radical-induced oxidative stress (Abd El-Salam, Heba, 2006).

Data also show that, the values of ASA and GSH concentrations as well as CAT, GPOD and SOD in Baramuda cv was found to be less than that of Sakkoty cv over all treatments. This indicated that Bartamuda cv has high ability to used AsA and GSH specially the latter, in the synthesis of thio containing molecules, particularly salfhydryl-containin amino acids; A A GSH and PG. Cysteine is required for GSH synthesis which, in turn, is required in PCs synthesis. PCs are able to create complex compounds with toxic ions (Piechalka et al, 2002) transported into the vacuole by the ABC transporter which is localized in the tonoplast (Oritz et al, 1995) thus separating them from cell metabolism. 


\section{REFERENCES}

Abdel-Salam; Heba, M. I.(2006). Phytochemical studies on certain Fabaceoes plants grown under heavy matals stress. Ph.D.Tesis Faculty of Agric. Mansoura Univ. Egypt.

Al-khateeb A, (2008). Comparison Effects of Sucrose and Date palm Syrup on Somatic Embryogenesis of Date Palm (Phoenix dactylifera L ). American Journal of Biotechnology and Biochemistry 4 (1): 19- 23

Apavatjrut, P. and Black, J. (1977). Tissue culture of stem explants of cocnut (Cocos nuciferal, L.)Gleag, 32(6): 267-271.

Arrigoni, O.; De Gara L.; Tommasi, F.and Liso, R. (1992). Changes in the ascorbae system during seed development of Vicia faba L. Plant Physiol., 99: 235-238.

Bates, L. S.; Waldren R. P. and Teare I. D. (1973). Rapid determination of free proline for water-stress studied. Plant and Soil, 39: 205-207.

Bekheet S.A.; Taha H.S.; Hanafy M.S. and Solliman .E.(2008).Morphogenesis of Sexual Embryos of Date Palm Cultured In vitro and Early Identification of Sex Type. Journal of Applied Sciences Research, 4(4): 345-352, 208.

Bekkaoui, F.; Saxena, P.K.; Attre, S.M.; Powke, L.C. and Dunstan, D.I. (1987). The isolation and culture of protoplasts from an embryogenic cell suspension culture of Picea glauca (moench) voss. Plant Cell Reports, 476-479.

Cakmak, I. and Marschner, H. (1992). Magnesium deficiency and high light intensity enhance activities of superoxide dismutase, ascorbate peroxidase and glutathione reductase in bean leaves. Plant Physiol., 98; $1222-1227$.

Cheng, S. (2003). Effects of heavy metals on plants and resistance mechanisms. Environ. Sci. Pollut. Res., 10: 256-264.

Danial, H.D. and George C.M. (1972). Peach seed dormancy in relation to endogenous inhibitors and applied growth substances. J. Am. Soc. Hort. Sci. 17: 651-654.

El-Hosiny, Hanan (2002). Effects of some growth factors on structure and growth behaviour of stem shoot tip cultures of date palm (Phoenix dactylifera, L.). M.Sc. Thesis Faculty of Agric Mansoura Univ. Egypt.

El-Meskaoui, A. and Tremblay, F. M. (2001). Involvement of ethylene in the maturation of black spruce embryogenic cell lines with different maturation capacities. J. Exp. Bot., 52: 761-679.

El-Shafey, Y.H.; Nesiem, M.R.A.; Habib, M.W. and Abdel-Sattar, M.M.(1999): Browning phenomenon a serious problem in date palm, conf. of date palm, Assiut University, Egypt, pp.53-74.

Forrest, G.L. (1969). Studies on the poly phenol metabolism of tissue culture derived from the tea plant (Camellia sinensis H.). Biochem. J. 113: 765-772.

Foyer, C.H.; Descouviers, K.J. abd Kunert, K.J. (1994). Protection against oxygen redicals: an important defense mechanism studied in transgenic plants. Plant Cell Environ., 17: 507-523. 
Grambow, H.J. and Langenbeck-Schwich B. (1983). The relationship between oxidase activity, peroxidase activity, hydrogen peroxide and phenolic compounds in the degradation of indole-3-acetic acid in vitro. Planta. 157:131-137.

Guo, Z.; Tan, H.; Zhu, Z.; Lu, S. and Zhou, B. (2005). Effect of intermediates on ascorbic acid and oxalate biosynthesis of rice and in relation to its stress resistance. Plant Physiol. Biochem., 43: 955-962.

Hegazy,A. (2003). Some physiological studies on date palm micropropagation through direct somatic embryogenesis. Ph.D. ThesisFaculty of Agric Cairo Univ. Egypt.

Hu, C.Y. and Wang, P.J. (1983). Merstim shoot tip and bud cultures. 177217. In: D.A Evans, W.R.; Ammirato, P.V.; Yama, Y. (eds). Handbook of Plant cell culture, I, Mac Millan, New York.

Ibrahim,I.A. and Hegazy , A. (2001 b).In vitro cultivation of date palm. 3- Date palm abonormalities during micropropagation via embryogenesis. MidAtlantic plant molecular Biology Society, Eighteenth Annual Meeting, Beltisville-MD, USA, August 2-3, pp. 39.

Ibrahim,I.A. and Hegazy, A. (2001a).In vitro cultivation of date palm. 1Micropropagation of adult and juvenile date palm. Mid-Atlantic plant molecular Biology Society, Eighteenth Annual Meeting, Beltisville-MD, USA, August 2-3, 2001, pp. 37.

Ichihashi, S. and Kako, S. (1977). Studies on clonal propagation of cattleya through tissue culture method. II. Browning of cattleya. J. Jap. Soc. Hort. Sci., 46: 325-330.]

Jiang, W.; Liu, D. and Liu, X. (2001). Effects of copper on root growth, cell division, and nucleolus of Zea mays. Biol. Plant., 44: 105-109.

Khalil, M.S.; Khan, M.A. and El-Kahtani, M.S. (1983). In vitro embryo culture of date palm (Phoenix dactylifera, L). $1^{\text {st }}$ Symp. On the date palm in Saudi Arabia, 142-149.

Lee, M. and Kirby, E.G. (1986). Growth promoters of cell suspension cultures (Psudotsugemenziesil) and effects of nitrogen sources on growth. New Zealand. J. of Forestry Sci., 16(3): 369-367.

Munne-Bosch,S.(2005). The role of -tocopherol in plant stress tolerance. J. Plant Physiol., 162: 743-748.

Murashige T (1974). Plant propagation through tissue culture. Ann. Rev. Plant Physiol. 25: 153-166.

Murashige, T. \& F. Skoog. 1962. A revised medium for rapid growth and bioassays with tobacco tissue cultures. Physiologia Plantarum, 15 (3): 473-497

Nash, D.T. and Davies, M.E.D. (1972). Some aspects of growth and metabolism of (Paul's scarlet) cell suspension. J. Ext. Bot., 23: 75-91.

Nour, G.M.; Khalifa, A.S.; Hussein, A.A.M. and Moustafa, A.A. (1986): Studies on the evaluation of fruit characteristics on nine dry date palm cultivars grown at Aswan. The $2^{\text {nd }}$ symposium on Date palm King Faisal Univ., Al-Hassa, Saudi, pp. 163. of Sciences of the USA 86: 891-895. 
Oritz, D.F.; Ruscitti, T.; McVue, K.F. and Ow, D.W. (1995). Transport of metal-binding peptides by HMTI, a fission yeast ABC-type vacuolar membrane protein. J. Biol. Chem., 270: 4721-4728.

Piechalka, A.; toaszewska, B.; Baralkiewicz, D. and Malecka, A (2002). Accumulation and detoxification of lead ions in legumes. Phytochemistry, 60: 153-162.

Pierik, R.L.M. (1987). In vitro culture of higher plants, Martinus, Nijhoff Pub. Dordrecht, Boston, Lancaster, p 66-79.

Pierik, R.L.M. (1989). In vitro Culture of Higher Plants. Martinus Nijhoff Publishers, Netherlands.

Plant Physiol. 25: 135-166.

Pierik, R.L.M. (1987). In vitro culture of higher plants, Martinus, Nijhoff Pub. Dordrecht, Boston, Lancaster, p 66-79.

Pierik, R.L.M. (1989). In vitro Culture of Higher Plants. Martinus Nijhoff Publishers, Netherlands. Plant Physiol. 25: 135-166.

Pottino, B.G. (1981). Methods in Plant Tissue Culture. Dept. of Hort. Agric. Collage, Maryland Univ., Collage, Park, Maryland, USA 8-29.

Prathanturarug, S.; Sachaffner, W.; Berger-Buter, K. and Pank, F. (1996). In vitro propagation of the Thai medicinal plant Andrographis Paniculata Nees. Proc. Intern. Symp. Breed. Res. On medicinal and aromatic plants,quedlinburg, Germany, 30 June 4 July, 1996. Bitrage-zurZuchtungsforschung-Bundesanstalt-fur-Zuchtungsforschungan Kulturpflanzen. 2: 1, 304-306.

Rhodes, J.M. and Wooltoron, L.S.C. (1978). The biosynthesis of phenolic compounds in wounded plant storage tissues. In: G. Kahl (ed) Biochemistry of wounded plant tissue. Walter de Gruyter and Co. Berlin, P. 243-286.

Sanchez-fernandez, R.; Fricker, M.; Corben, L-B; White, N.S.; Sheard, N.; Leaver, C.J.; Van Montagu, M.; Inze, D. and May, M.J. (1997). Cell proliferation and hair tipgrowth in the Arabidopsis root are under mechanistically different forms of redox control. Proc. Natl. Acad. Sci. U.S.A., 94: 2745-2750.

Schwendiman, J.; Pannetier, C., and Michaux-Ferriere N. (1988). Histology of somatic embryogenesis from leaf explants of the oil palm Elaeis guineensis. Annals of Botany 62: 43-52.Science 41: 125-132.

Smeets, K.; Cuypers, A.; Lambrechts, A.; Semane, B.; Hoet, P.; Van Laere, A. and vangronsveld, J. (2005). Induction of oxidative stress and antioxidative mechanisms in Phaseolus vulgaris after $\mathrm{Cd}$ application. Plant Physiol. Biochem., 43: 437-444.

Suprasanna, P.; Roa, K.V. and Reddy, G.M. (1994). Embryogenic callus in maize, genotype and amino acid effects. Cereal Research Communications, 22(1-2): 79-82.

Swain, T. and Hills, W. E (1959). The quantitative analysis of phenolic constituent. J. Sci. Food Agric., 10: 63.

Tisserat, B. (1979a). Tissue culture of the date palm. J. of Heredity, 70(3): 221-222. 
Tisserat, B. (1979b). Propagation of date palm (Phoenix dactylifera, L). in vitro J. of Exp. Bot., 30: 1275-1283.

Tisserat, B. (1984a). Propagation of date palms by shoot tip cultures. Hort. Sci., 19(2): 230-231.

Tisserat, B. (1984b). Date Palm in Sharp, W.R.; Evans, D.A.; Ammirato, P.V. and Yamado, Y. (eds). Hand Book of Plant Cell Culture, 2, Mc Millian, New York, p 505-545.

Urbanek, H.; Kuzniak-Gebarowska, E. and Herka, H. (1991). Elicitation of defense responses in bean leaves by Botrytis cinerea polygalacturonase. Acta Physiol. Plant., 13: 43-50.

Van Rossun, M. W.P.C.; Alberda, M. and Van Der Plas, L.H.W. (1997). Role of oxidative damage in tulip scale micropropagation. Plant Sci., 130: 207-216.

Velikova, V.; yordanov, I. and Edreva, A. (2000). Oxidative stress and some antioxidant system in acid rain-treated bean plants protective role of exogenous polyamines. Plant Sci., 151: 59-66.

Wingate, V.P.M.; Lawton, M.A. and Lamb, C.J. (1988). Glutathione causes a massive and selective induction of plant defense genes. Plant physiol., 31: 205-211.

Zaid, A. (1986). Review of date palm (Phoenix dactylifera L.) tissue culture. Proceeding of the $2^{\text {nd }}$ Symposium on Date Palm, King Faisal Univ. AlHassa, Saudi Arabia, March 3-6, 1: 67-75.

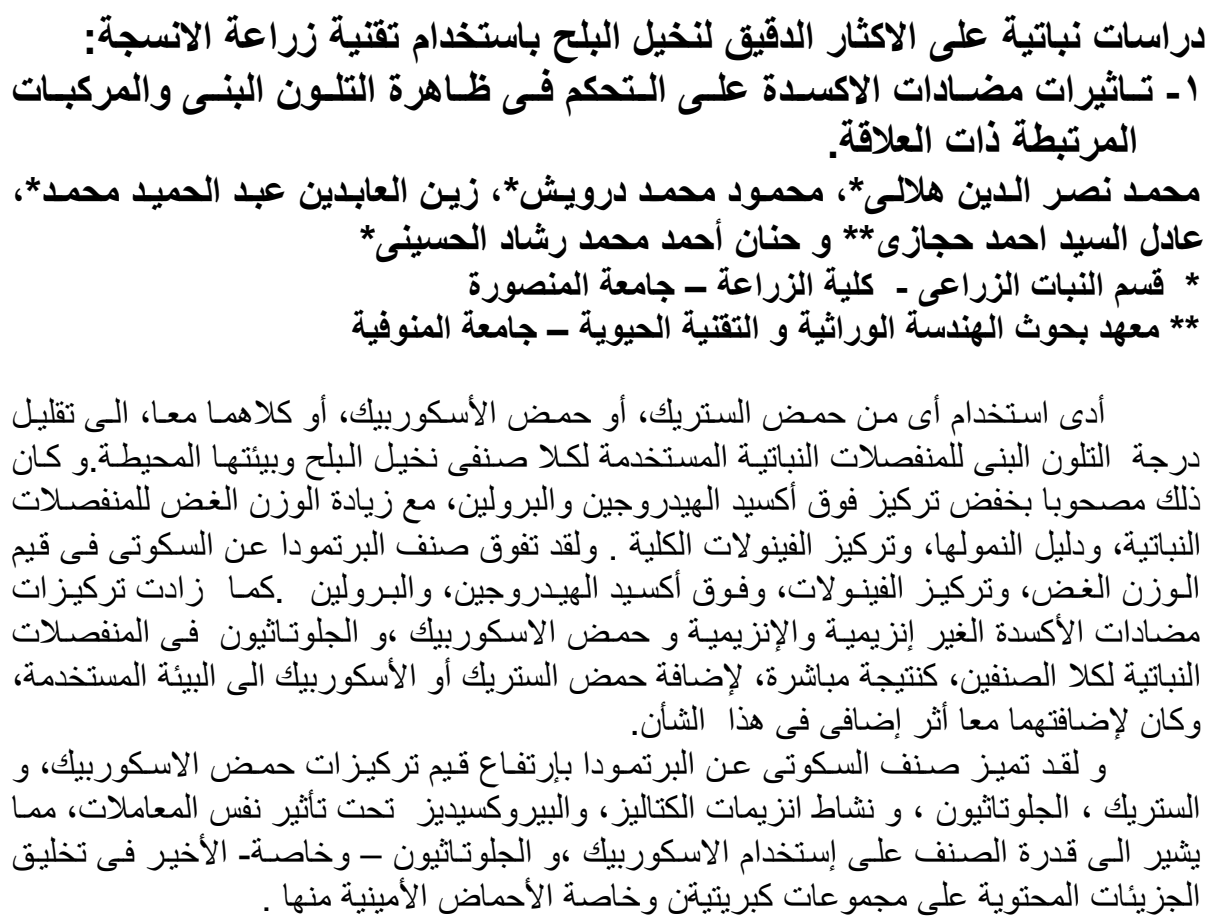

